\title{
The Evaluation of Hba1c Test as A Diagnostic Test for Diabetes Mellitus Type 2
}

\author{
Osamah Zaki Bakr \\ Ministry of Industry and Minerals, Mosul, Iraq \\ E-mail: osamazaki.20102020@gmail
}

(Received June 04, 2021; Accepted June 30, 2021; Available online August 28, 2021)

DOI: 10.33899/edusj.2000.168658, () 2021, College of Education for Pure Science, University of Mosul.

This is an open access article under the CC BY 4.0 license (http://creativecommons.org/licenses/by/4.0/).

\begin{abstract}
The HbAlc test and the blood glucose test were compared in order to diagnose type 2 diabetes and determine the best cut-off point for the HbA1c test for optimal sensitivity in the population of Mosul city (inside it and some rural areas around it). The test was performed on a group of people between the ages of 40 and 85 who came to our laboratory after being diagnosed with or without type 2 diabetes by specialists in internal medicine and endocrinology. The HbA1c and FBS analysis were carried out between January 2020 and January 2021. And, by using ROC curve, the results for 80 individuals with an average age of 56 years produced a HbA1c test with a value of 6.8 percent, a sensitivity of 94 percent, compared to the result of $126 \mathrm{mg} / \mathrm{ml}$ for FBS as a diagnostic criterion , and the optimal cutoff point for $\mathrm{HbA} 1 \mathrm{c}$ was reached for $6.86 \%$ in diagnosing disease diabetes type 2 was given the highest Yuden index by ROC curve analysis. Conclusion: We recommend that the optimal value of $\mathrm{Hb}^{2}$ with a percentage of 6.86 percent be used as the best test in diagnosing type 2 diabetes and obtaining the best medical and health care for the Mosul population.
\end{abstract}

Keyword: HbA1c, Diabetes, Type 2

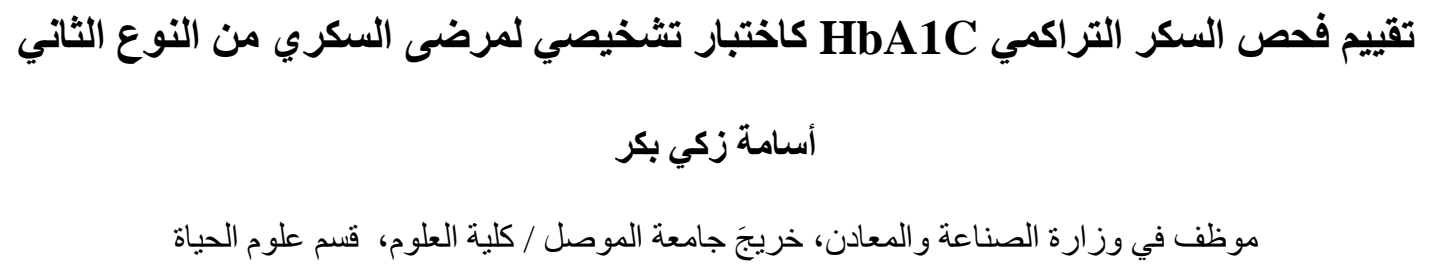

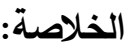

تم إجراء دراسة مقارنة بين فحص السكر التراكمي HbA1C وفحص الجلوكوز في الدم لغرض تشخيص مرض السكري من

النوع الثاني وإيجاد نقطة القطع المثلى لاختبار الـ HbA1c من أجل الوصول الى الحساسية المثلى للفحص لدى سكان مدينة الموصل (من داخل المدينة وبعض المناطق الريفية المحيطة بها). تم إجراء الفحص على مجموعة من الأثخاص تتراوح أعمارهم بين 40 و 85 عامًا ممن حضروا إلى مختبرنا وتم تثخيص إصابتهم بالسكري من النوع الثاني أو عدمه من قبل المتخصصين في الطب الباطني 


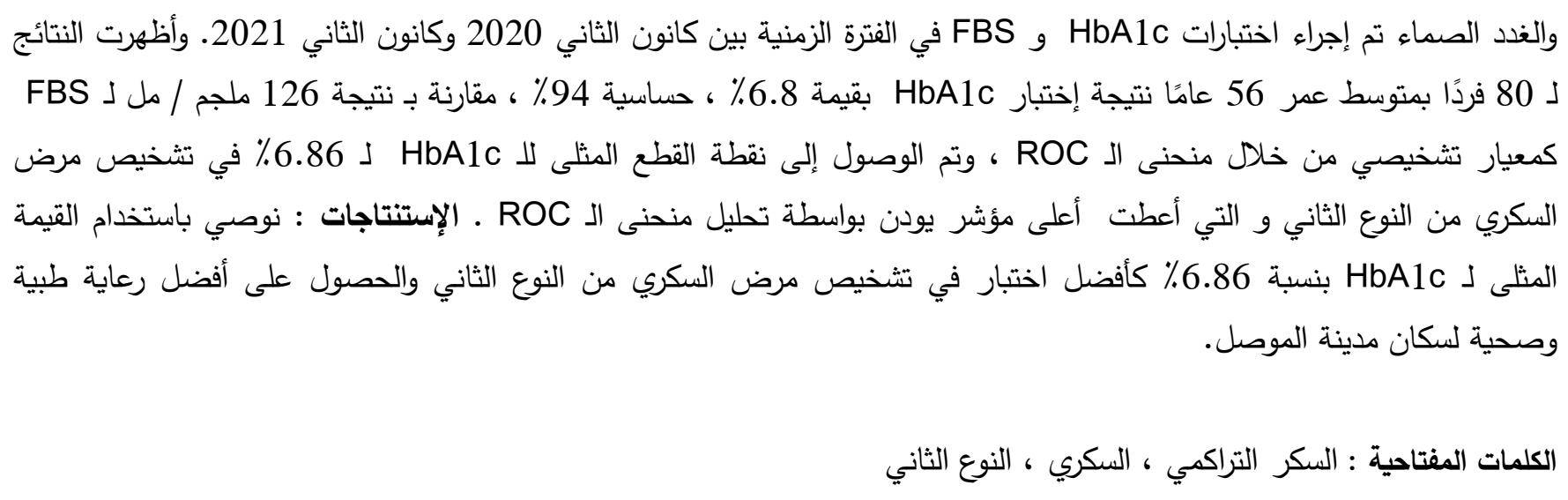

\section{Introduction}

Diabetes is a chronic metabolic disease characterized by high blood sugar levels, and it causes significant damage to the nerves, blood vessels, kidneys, and eyes over time (IDF2013). ${ }^{1}$ Diabetes type 2 has become the most common and prevalent in the last four decades. The incidence of this disease has increased in all countries and at all levels. More than 422 million people in the world suffer from diabetes type 2. Also, 1.6 million deaths every year are attributed to this disease (Brooks et al). ${ }^{2}$ And there is a global agreement to prevent this disease and eliminate obesity by $2025 .{ }^{1}$ Diabetes type 2 is characterized by a long clinical phase, so early and accurate diagnosis is critical (Singer et al). ${ }^{3}$ The World Health Organization recommends using a 6.5 percent glycated hemoglobin HbAlc test as the diagnostic cut-off limit for this disease. HbA1c is primarily defined as an atypical hemoglobin for diabetics over the age of forty years. ${ }^{4,5}$ Glycoproteins are formed after conversion through a slow, nonenzymatic interaction between blood sugar (glucose) and amino groups on proteins, which is an important and clinically useful indicator. For average blood sugar during the previous 120 days ( which is the average age of red blood cells). ${ }^{6}$ and the introduction of the HbAlc test as a diagnostic tool for diabetes and the cut-off point is the focus of controversy and study for many years, and many studies have been conducted in this field and for residents from different countries to reach the limit. ${ }^{7}$ Diagnostic interval. Carefully controlled studies have documented a close relationship between $\mathrm{HbAlc}$ concentration and glycemic control. And in this regard, the people of Mosul should be provided with a high level of care in order to avoid spreading the disease. As a result, this study was carried out to determine the cut-off value and diagnostic tool for HbAlc levels in the Mosul population.

\section{Materials And Methods}

The study was conducted in a specialized pathology analysis laboratory licensed by the Iraqi Ministry of Health on 80 residents of Mosul from January 2020 to January 2021, all of whom were over 40 years old. As 17 of them were diagnosed as having diabetes type 2 by certified specialists who were newly diagnosed with monitoring their blood pressure measurement. Diabetes is diagnosed by measuring blood glucose levels after fasting for 8 to 12 hours and finding that the level is greater than $126 \mathrm{mg} / \mathrm{dl}$. Their infection was known from taking the treatment. Those with a history of blood transfusions within three months, those taking aspirin, and those with chronic liver and kidney disease were excluded. The family history of diabetes was studied for each individual along with age, height, 
weight, blood pressure, waist circumference and hip circumference. Boditech's I CHROMA TM II +® kit was used to measure HbA1c levels. HbA1c and total hemoglobin are measured using integrated advanced immunoassay and dry chemistry technology, respectively. The capillary blood sample was used with appropriate precautions. Calibrated according to the blood sample set and other standard materials supplied to us by the manufacturer.

\section{Statistics}

The analysis was carried out using the statistical software program Minitab version 17 with the assistance of statistical experts. The SPSS program version 23 was used to create the sensitivity curve and the rock curve, and all of these programs are available on my personal computer.

\section{Ethics}

The consent of all study subjects was obtained. Note that it is an analytical and statistical study and it did not harm any individual material, health or moral.

\section{Thanks and Appreciation}

I extend my thanks and gratitude to Al-Kawthar Laboratory for Pathological Analysis (a private laboratory licensed by the Iraqi Ministry of Health) for helping me complete the practical aspect of the research.

\section{Results}

The diabetes type 2 group consisted of 9 females and 8 males, while the non-diabetic group consisted of 36 females and 27 males among the 63 people. Table No. 1 shows the characteristics of the study participants. With the determination of HbA1c values, the blood glucose test (FBS) was adopted as a diagnostic criterion for type 2 diabetes with the estimation of HbA1c levels (Table No. 2) To determine the relationship between FBS and HbA1c (Fig. 1), a linear regression analysis was performed, and the stability of the highest and most credible analysis degree was demonstrated (Table No. 3, 4 and 5) and the equation produced the relationship between the two tests was produced by the equation:

$\operatorname{HbA1c}(\%)=2.021+0.03932 \times$ FBS $(\mathrm{mg} / \mathrm{dl})$

And for the value of $126 \mathrm{mg} / \mathrm{dl}$ for the FBS test, it is $6.97 \%$, and for the value for $6.5 \%$ for the Hb1Ac test, the value is $113.911 \mathrm{mg} / \mathrm{dl}$.

Table 1 : A comparison of patient groups

\begin{tabular}{lll}
\hline Variables & Diabetic & Non Diabetic \\
\hline Age & $57.25 \pm 8.25$ & $56.04 \pm 6.52$ \\
BMI & $22.13 \pm 1.98$ & $21.83 \pm 2.07$ \\
Waist circumference & $90.21 \pm 5.65$ & $89.23 \pm 5.17$ \\
Hip circumference & $92.81 \pm 5.03$ & $88.16 \pm 4.18$ \\
\hline
\end{tabular}


Table 2: HbA1c diagnostic performance comparison

\begin{tabular}{cccc}
\hline & \multicolumn{3}{c}{ HbA1c (\%) } \\
\cline { 2 - 3 } FBS (mg/d) & $\geq 6.5$ & $<6.5$ & TOTAL \\
$<126$ & 18 & 45 & $\mathbf{6 3}$ \\
$\geq 126$ & 17 & 0 & $\mathbf{1 7}$ \\
\hline
\end{tabular}

Table 3: Analysis of Variance

\begin{tabular}{cccccc}
\hline Source & DF & Adj SS & Adj MS & F-Value & P-Value \\
\hline Regression & 1 & 41.4591 & 41.4591 & 1454.11 & 0.000 \\
FBS (mg/dl) & 1 & 41.4591 & 41.4591 & 1454.11 & 0.000 \\
Error & 78 & 2.2239 & 0.0285 & & \\
Lack-of-Fit & 47 & 1.6434 & 0.0350 & 1.87 & 0.034 \\
Pure Error & 31 & 0.5805 & 0.0187 & & \\
Total & 79 & 43.6830 & & & \\
\hline
\end{tabular}

Table 4: Model Summary

\begin{tabular}{cccc}
\hline $\mathbf{S}$ & R-sq & R-sq(adj) & R-sq(pred) \\
\hline $\mathbf{0 . 1 6 8 8 5 4}$ & $94.91 \%$ & $94.84 \%$ & $94.47 \%$ \\
\hline
\end{tabular}

Table 5: Coefficients

\begin{tabular}{cccccc}
\hline Term & Coef & SE Coef & T-Value & P-Value & VIF \\
\hline Constant & 2.021 & 0.117 & 17.34 & 0.000 & \\
FBS (mg/dl) & 0.03932 & 0.00103 & 38.13 & 0.000 & 1.00 \\
\hline
\end{tabular}


Journal of Education and Science (ISSN 1812-125X), Vol: 30, No: 3, 2021 (95-103)

Special Issue for Proceeding of $3^{\text {rd }}$ National (1 $1^{\text {st }}$ international conference of biology) (ICBSUM 2021) 5, 6 July

College of Education for Pure Science, University of Mosul, Mosul, Iraq.

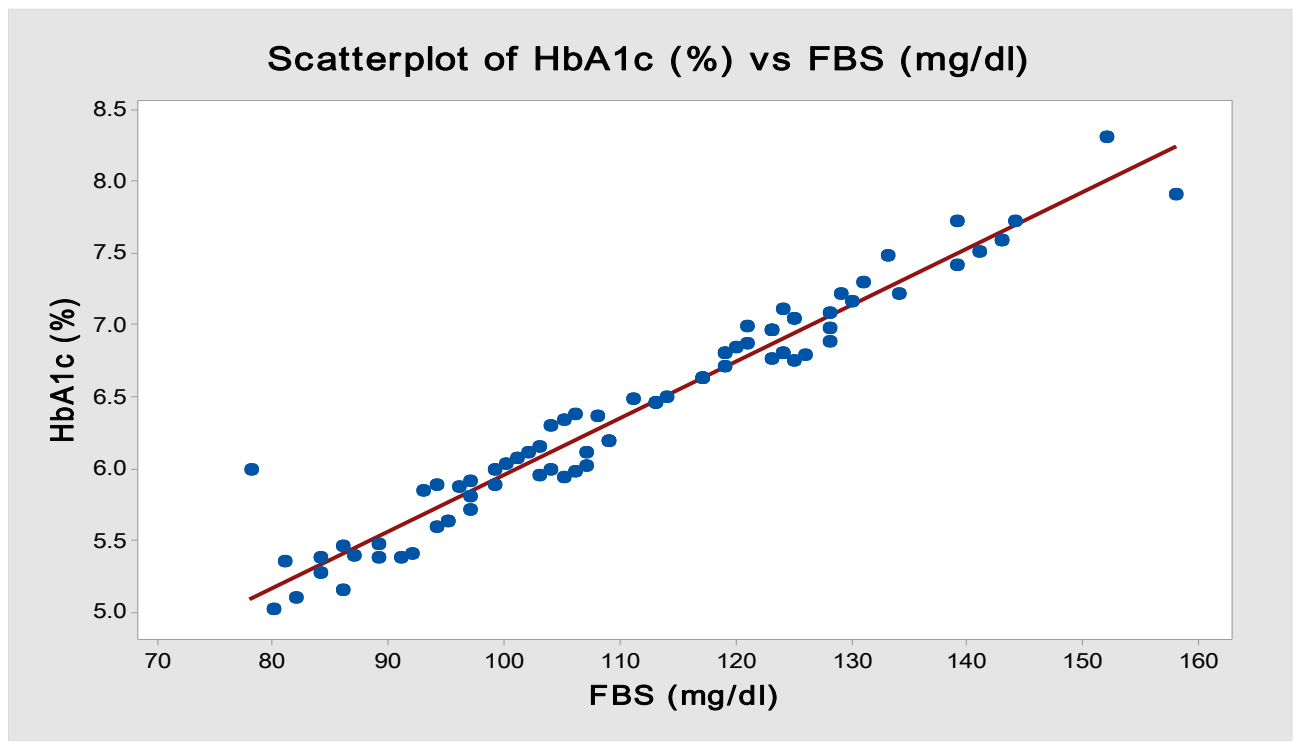

Figure 1: Regression Analysis: HbA1c (\%) versus FBS (mg/dl)

A rocker curve was created to determine the optimal cut for the resulting values (Fig. 2) (Table No. 6). The value $6.5 \%$ for HbA1c assay showed a sensitivity of $100 \%$ and the optimum cutoff value for $\mathrm{HbA1c}$ assay was $6.86 \%$, which recorded a sensitivity of $94 \%$, which gave the maximum Youden Index. With a value of $84 \%$ (Table No. $7 \&$ histogram).

Table 6: Area Under the Curve. Test Result Variable(s): HbAlc

\begin{tabular}{ccccc}
\hline Area & Std. Error $^{\mathrm{a}}$ & Asymptotic Sig. $^{\text {b }^{\prime}}$ & \multicolumn{2}{c}{$\begin{array}{c}\text { Asymptotic 95\% Confidence } \\
\text { Interval }\end{array}$} \\
\cline { 3 - 4 } & & & Lower Bound & Upper Bound \\
.979 & .014 & .000 & .951 & 1.000 \\
\hline
\end{tabular}

a. Under the nonparametric assumption b. Null hypothesis: true area $=0.5$ 


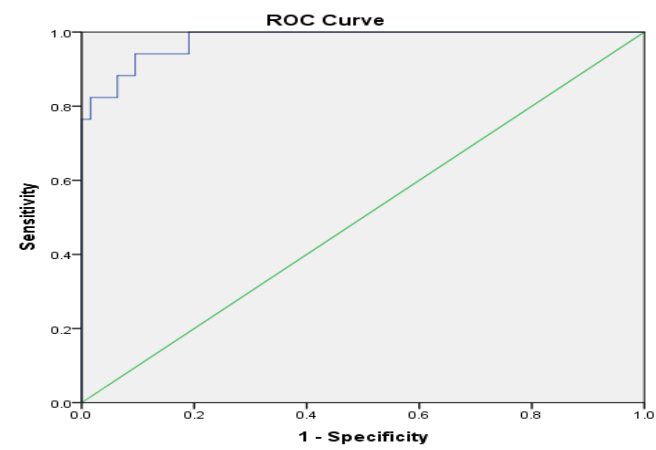

Figure 2: ROC curve

Table 7: Coordinates of the Curve. Test Result Variable(s): HbAlc

\begin{tabular}{cccc}
\hline Positive if Greater Than or Equal To $^{\text {a }}$ & Sensitivity & 1 - Specificity & Youden Index \\
\hline 6.555 & 1 & 0.286 & 0.714 \\
6.66 & 1 & 0.238 & 0.762 \\
6.72 & 1 & 0.222 & 0.778 \\
6.75 & 1 & 0.206 & 0.794 \\
6.77 & 1 & 0.19 & 0.81 \\
6.79 & 0.941 & 0.19 & 0.751 \\
6.82 & 0.941 & 0.127 & 0.814 \\
6.85 & 0.941 & 0.111 & 0.83 \\
6.865 & 0.941 & 0.095 & 0.846 \\
6.915 & 0.882 & 0.095 & 0.787 \\
6.965 & 0.882 & 0.063 & 0.819 \\
6.975 & 0.824 & 0.063 & 0.761 \\
7.01 & 0.824 & 0.048 & 0.776 \\
7.055 & 0.824 & 0.016 & 0.808 \\
7.085 & 0.765 & 0.016 & 0.749 \\
\hline 7.125 & 0.765 & 0 & 0.765 \\
& & 0.846 & 0.846 \\
\hline
\end{tabular}

a. The smallest cutoff value is the minimum observed test value minus 1, and the largest cutoff value is the maximum observed test value plus 1 . All the other cutoff values are the averages of two consecutive ordered observed test values. 


\section{Discussion}

It is known that the HbA1c test has a lower sensitivity in Europeans compared to Asians, as was indicated by Mustafa $e t a l^{8}$. In this study, we demonstrated the high sensitivity of the HbA1c test for Mosul residents, and the value of $6.5 \%$ is a sensitivity of $100 \%$, which is an extremely high value. Also, the linear relationship between FBS test and HbA1c test is HbA1c $=1.51+0.0414 \times$ FPG as explained by Liang et $a l^{9}$, which gives the value $6.72 \%$ for the test of HbA1c compared with the value of $126 \mathrm{mg} / \mathrm{dl}$ for the test. It gives a value of $120.5 \mathrm{mg} / \mathrm{dl}$ for $6.5 \%$ of the HbA1c test. And our linear analysis showed that the most accurate and the most sensitive relationship is HbA1c $(\%)=2.021+$ $0.03932 \times \mathrm{FBS}(\mathrm{mg} / \mathrm{dl})$, so the ratio of $\mathrm{FBS}=126 \mathrm{mg} / \mathrm{dl}$ is equal to $6.97 \%$ of $\mathrm{HbA} 1 \mathrm{c}$ and for the value of $6.5 \%$ of $\mathrm{HbA} 1 \mathrm{c}$ is equivalent to $113.911 \mathrm{mg}$ In his study, Ogawa et al ${ }^{10}$ suggested that the FBS value of $111.4 \mathrm{mg} / \mathrm{dl}$ is equivalent to $6.5 \%$ of HbA1c and is lower than what was suggested by the World Health Organization, and the FBS value $=126 \mathrm{mg} / \mathrm{dl}$ is equivalent to $7.5 \%$ of $\mathrm{HbA} 1 \mathrm{c}$ in the region. his study. The question of the cut-off value of HbA1c testing in diagnosing diabetes type 2 is a subject of controversy and debate all over the world. Scientists have suggested Gomyo et al ${ }^{11}$, Farhan et al ${ }^{12}$, Adamska et $a l^{13}$, Martin et al ${ }^{14}$, Bae et al ${ }^{15}$, Tankova et al ${ }^{16}$, Ghazanfari et al ${ }^{17}$, Li et al ${ }^{18}$, Kim et al ${ }^{19}$ The following values are 5.5,5.8, 5.9,5.9, 5.95, 6.1, 6.15, 6.3 and 6.45, which are all below the limit set by the World Health Organization, respectively. There are also studies that have put values higher than those set by the World Health Organization as in Jung et al ${ }^{20}(6.75 \%)$ and Higgins et al ${ }^{21}(7 \%)$. A 6year study conducted by (NHANES) Buell et al ${ }^{22}$ (National Health and Nutrition Examination Survey) suggested $7 \%$ as the cut-off value for diagnosis. The Association of British Diabetes Doctors ${ }^{23,24}$ (ABCD) provided a higher level of $7.2 \%$ to reduce the incidence of diabetes type 2 . The US Department of Defense's Veterans Affairs also introduced a 7\% cut-off point for the HbA1c test. ${ }^{25,26}$ In this study, we excluded many factors that impair access to the ideal focal point, such as kidney failure, anemia, blood transfusion, and taking medications that affect the study. Conducting such studies on the population of the city of Mosul is considered to be of great benefit in diagnosing or controlling diseases, especially chronic diseases.

\section{Conclusions}

A cut-off value of $6.86 \%$ is considered the diagnostic criterion for diabetes type 2 as it gave the optimum sensitivity to the HbA1c test. The relationship between HbA1c and FBS is: HbA1c $(\%)=$ $2.021+0.03932 \times$ FBS $(\mathrm{mg} / \mathrm{dl})$

\section{Reference}

1. International Diabetes Federation. IDF Diabetes Atlas 6th ed. IDF. Brussels. 2013.

2. Brooks DE, Devine DV, Harris PC, et al. RAMP(TM): A rapid, quantitative whole blood immunochromatographic platform for point of care testing. Clin Chem 1999; 45:1676-1678.

3. Singer DE, Coley CM, Samet JH, Nathan DM. Tests of glycemia in diabetes mellitus. Their use in establishing a diagnosis and in treatment. Ann Intern Med 1989; 110:125-37.

4. Tahara Y, Shima K. Kinetics of HbA1c, glycated albumin, and fructosamine and analysis of their weight functions against preceding plasma glucose level. Diabetes Care 1995; 18:440-7. 
5. UK Prospective Diabetes Study. Reduction in HbA1c with basal insulin supplement, sulfonylurea or biguanide therapy in maturity-onset diabetes. Diabetes 1985; 34:793-8.

6. Nathan DM, Twrgeon H and Regan S. Relationship between glycated hemoglobin levels and mean glucose levels over time. Diabetologia 2007; 50:2240-2245.

7. Herman WH, Ma Y, Uwaifo G, Haffner S, Kahn SE, Horton ES, Lachin JM, Montez MG, Brenneman T, Barrett-Connor E. Differences in A1C by race and ethnicity among patients with impaired glucose tolerance in the Diabetes Prevention Program. Diabetes care. 2007 Oct 1;30(10):2453-7.

8. Mostafa SA, Khunti K, Kilpatrick ES, Webb D, Srinivasan BT, Gray LJ, et al. Diagnostic performance of using one- or two- HbA1c cut-point strategies to detect undiagnosed type 2 diabetes and impaired glucose regulation within a multi-ethnic population. Diab Vasc Dis Res 2013; 10(1):83-93.

9. Liang K, Sun Y, Li WJ, Zhang XP, Li CQ, Yang WF, et al. Diagnostic Effi ciency of Hemoglobin A1c for Newly Diagnosed Diabetes and Prediabetes in Community-Based Chinese Adults Aged 40 Years or Older. Diabetes Technol Ther 2014; 16(12):852-858.

10. Ogawa E, Urakami T, Suzuki J, Yoshida A, Takahashi S and Mugishima H. Usefulness of HbA1c to diagnose diabetes among Japanese children detected by a urine glucose screening program in the Tokyo Metropolitan Area. Endocr J 2012; 30: 59(6):464-472.

11. Gomyo, M, Sakane N, Kamae I, Sato S, Suzuki K, Tominaga M, et al. Effects of sex, age and BMI on screening tests for impaired glucose tolerance. Diabetes Research and Clinical Practice 2004; 64(2):128-137.

12. Farhan S, Jarai R, Tentzeris I, Kautzky-Willer A, Samaha E, Smetana P, et al. Comparison of hba1c and oral glucose tolerance test for diagnosis of diabetes in patients with coronary artery disease. Clin res cardiol 2012; 101(8):624-631.

13. Adamska E, Waszczeniuk M, Gościk J, Golonko A, Wilk J, Pliszka J, et al. The usefulness of glycated hemoglobin A1c (HbA1c) for identifying dysglycemic states in individuals without previously diagnosed diabetes. Adv Med Sci 2012; 57(2):295-302.

14. Martin E, Ruf E, Landgraf R, Hauner H, Weinauer F and Martin S. FINDRISK questionnaire combined with HbA1c testing as a potential screening strategy for undiagnosed diabetes in a healthy population. Horm Metab Res 2011; 43(11):782-787.

15. Bae JC, Rhee EJ, Choi ES, Kim JH, Kim WJ, Yoo SH, et al. The cutoff value of HbA1c in predicting diabetes in Korean adults in a university hospital in Seoul. Korean Diabetes J 2009; 33:502-511.

16. Tankova T, Chakarova N, Dakovska L and Atanassova I. Assessment of HbA1c as a diagnostic tool in diabetes and prediabetes. Acta diabetol 2012; 49(5):370-379. 
Journal of Education and Science (ISSN 1812-125X), Vol: 30, No: 3, 2021 (95-103)

Special Issue for Proceeding of $3^{\text {rd }}$ National (1 ${ }^{\text {st }}$ international conference of biology) (ICBSUM 2021) 5, 6 July

College of Education for Pure Science, University of Mosul, Mosul, Iraq.

17. Ghazanfari Z, Haghdoost AA, Alizadeh SM, Atapour J, Zolala F. A comparison of HbA1c and fasting blood sugar tests in general population. International journal of preventive medicine. 2010;1(3):187.

18. Li LJ, Zhou JX, Chen HT, Song YL and Xue YM. Effect of HbA1c combined FPG on screening diabetes in health check-up. Asian Pac J Trop Med 2012; 5(6):471-476.

19. American Association of Clinical Endocrinologists. Board of Directors and American College of Endocrinologists Board of Trustees. American Association of Clinical Endocrinologists/American College of Endocrinologists statement on the use of hemoglobin A1c for the diagnosis of diabetes. Endocrine Pract 2010; 16:154-157.

20. Kim HJ, Choi EY, Park EW, Cheong YS, Lee HY and Kim JH. The Utility of HbA1c as a Diagnostic Criterion of Diabetes. Korean J Fam Med 2011; 32(7):382-370.

21. Higgins TN, Tran D, Cembrowski GS, Shalapay C, Steele P and Wiley C. Is HbA1c a good screening test for diabetes mellitus? Clin Biochem 2011; 44(17-18):1468-1473.

22. Buell C, Kermah D and Davidson MB. Utility of A1C for diabetes screening in the 1999-2004 NHANES population. Diabetes Care 2007; 30:2232-2236.

23. Jung JH, Kim ST, Cho Y Z, Lee HN, Kim JY, Kim JH, et al. Acceptability of HbA1c values as a diagnostic tool for diabetes mellitus in Korea. Korean J Med 2010; 79:672-681.

24. Kilpatrick ES and Winocour PH. ABCD position statement on haemoglobin A1c for the diagnosis of diabetes. Pract Diab Int 2010; 27:305-311.

25. American Diabetes Association. Diagnosis and Classification of Diabetes Mellitus. Diabetes Care 2011; 34 (Suppl 1): S61-S70.

26. Pogach L, Conlin PR, Hobbs C, Vigersky RA and Aron DC. VA-DoD update of diabetes guidelines: What clinicians need to know about absolute risk of benefits and harms and A1c laboratory accuracy. Federal Practitioner 2011;(April):38-45. 